\title{
The current position of surgical lung biopsy in the diagnosis of idiopathic pulmonary fibrosis
}

Riitta Kaarteenaho 1,2,3

\begin{abstract}
A new international statement defines usual interstitial pneumonia (UIP) which is a histological and radiological form of idiopathic pulmonary fibrosis (IPF) more precisely than previously. In the diagnosis of IPF, either in high resolution computed tomography (HRCT) a UIP pattern must be present or alternatively specific combinations of HRCT and surgical lung biopsy findings can be accepted. In about two third of the cases IPF can be diagnosed by clinical and radiological criteria. Thus surgical lung biopsy is needed in about one third of cases to achieve the ultimate diagnosis, which requires multidisciplinary cooperation. In large clinical trials conducted during the last decade, lung biopsy was performed in about $30-60 \%$ of the cases. The most serious complication of lung biopsy is mortality within 30 days after the procedure, with a frequency of about 3-4\% reported in most studies. Because of the histological variability, surgical lung biopsy should be taken from a minimum of two lobes. The number of fibroblast foci in surgical lung biopsy has been shown to correlate with survival in several studies.
\end{abstract}

Keywords: Fibroblast focus, Complication, Non-specific interstitial pneumonia, Open lung biopsy, Usual interstitial pneumonia, Video-assisted thoracoscopy

\section{Review}

Until recently, surgical lung biopsy (SLB) has been regarded as the golden standard in the diagnosis of idiopathic pulmonary fibrosis (IPF) and other types of idiopathic interstitial pneumonias (IIP). During the past decades, the pathological and clinical terms for the IIPs have been at least partly different which has been responsible for misinterpretations between different specialists working with the patients with IIP.

The new international statement on the diagnosis and management of IPF has recommended adopting a multidisciplinary approach for the ultimate diagnosis [1]. On the other hand, when a patient has a clinically and radiological typical usual interstitial pneumonia (UIP) with no known causes, the diagnosis can be made without bronchoscopy, transbronchial biopsy (TBB), bronchoalveolar lavage (BAL) or SLB procedures. Thus the role of the traditional investigative methods including SLB is currently changing. When previously, SLB has been performed as a

\footnotetext{
Correspondence: riitta.kaarteenaho@kuh.fi

${ }^{1}$ Unit of Medicine and Clinical Research, Pulmonary Division, University of Eastern Finland, PO Box 1777, Kuopio 70211, Finland

${ }^{2}$ Center for Medicine and Clinical Research, Division of Respiratory Medicine, Kuopio University Hospital, PO Box 1777, Kuopio 70211, Finland

Full list of author information is available at the end of the article
}

basic diagnostic tool for investigating a patient with suspected IPF, it is nowadays needed for the ultimate diagnosis of the non-typical IPF patients who do not fulfill the precise criteria for UIP in high-resolution computed tomography (HRCT) [2,3]. These non-typical IPF patients may have confounding aspects and other diseases, which can complicate the diagnostics. In this review article, the current histological criteria of UIP will be outlined as well the current awareness of the necessity, commonality and risks of SLB. The accuracy of histological diagnosis, the variability of the histological features and the significance of SLB as a prognostic tool are also discussed.

\section{Role of histological diagnostics in the 2011 international statement of IPF}

In a new statement, IPF is defined as a progressive interstitial pneumonia of unknown cause, occurring in adults, limited to the lungs and associated with the histological and/or radiological pattern of usual interstitial pneumonia (UIP). In the diagnosis of IPF, other known causes must be excluded, in HRCT, a UIP pattern must be present, or specific combinations of HRCT and SLB findings can be accepted. Further, there are no longer the so-called major or minor criteria present in the previous guidelines, and 
BAL or transbronchial biopsy is no longer required as was the case in the statement released in 2000 [1,4].

The new diagnostic criteria for radiology and histopathology are more precise than previously and now include 3 HRCT categories and 4 histological categories, namely 1) UIP, 2) possible UIP and 3) inconsistent with UIP for HRTC, and 1) UIP, 2) probable UIP, 3) possible UIP and 4) not UIP for histopathology. The histological categories are presented in detail in Table 1. In the typical UIP pattern, a marked fibrosis, a patchy involvement and fibroblast foci (FF) should be present (Figure 1).

The 2011 statement recommends adoption of the following diagnostic algorithm for patients with suspected IPF [1]. Patients should be carefully evaluated for identifiable causes of interstitial lung disease (ILD). In the absence of an identifiable cause for ILD, an HRCT demonstrating a UIP pattern is diagnostic of IPF. In the absence of a UIP pattern, and presence of possible UIP or not UIP features in HRCT, SLB should be performed after which IPF can be diagnosed by the examining combination of HRCT and histological patterns. The accuracy of the diagnosis of IPF has been shown to be increased if one conducts multidisciplinary discussions with other ILD experts [5].

\section{How often SLB is performed?}

The study of Raghu et al. indicated that IPF can be diagnosed by clinical and radiological criteria in about two third of all cases [6]. Subsequent studies have later confirmed that the characteristic HRCT features are absent in around $30 \%$ to $40 \%$ of IPF patients and thus, in about $1 / 3$ of IPF patients SLB may be needed to achieve an accurate diagnosis [7-11]. Hunninghake and co-authors found that an expert panel of pathologists was more accurate in making a diagnosis of IPF than a panel of radiologists and clinicians, and moreover, that accuracy was higher among the groups of experts than that for referral centers [8]. Another study revealed that the accuracy of the diagnosis of IPF increased with clinical, radiologic, and histological correlation [5].

The most common differential diagnostic problem is nonspecific interstitial pneumonia (NSIP). Flaherty and co-authors claimed that patients with an HRCT pattern of UIP are likely to exhibit a histological pattern of UIP, but the patients with an HRCT pattern other than UIP may have either histological UIP or NSIP in the SLB specimen, and that HRCT has limited specificity in identifying histological proven NSIP [7]. Silva and others observed that in $28 \%$ of the biopsy-proven NSIP cases, the HRCT features that were originally suggestive for NSIP changed to findings that were indicative of IPF [12]. Although CT features are typical for UIP in most case, sometimes CT findings may mimic NSIP, chronic hypersensitivity pneumonitis (HP) or sarcoidosis [13]. Some studies have revealed that HRCT may permit a distinction between NSIP and IPF in about $70 \%$ of patients $[14,15]$. However, a recent study showed, that the characteristic HRCT features of chronic HP, IPF and NSIP allow one to make a confident differentiation between these entities in approximately $50 \%$ of the patients [16].

There are some published data about the frequency of SLB in different countries, which have shown the actual incidence of SLB in routine clinical diagnostics during the 1990's and 2000's. Epidemiologic studies in Italy, Belgium, Greece, Spain, United States and Finland have revealed that the diagnosis has been confirmed by SLB in 28-38\% of the cases [17-22]. Questionnaire-based national surveys have shown that in Greece and Spain approximately $31 \%$ of the patients with IPF were diagnosed

Table 1 Histopathological criteria for UIP/IPF [1]

\begin{tabular}{|c|c|c|c|}
\hline 1. UIP pattern (All four criteria) & 2. Probable UIP pattern & $\begin{array}{l}\text { 3. Possible UIP pattern } \\
\text { (All three criteria) }\end{array}$ & $\begin{array}{l}\text { 4. Not UIP pattern } \\
\text { (Any of the six criteria) }\end{array}$ \\
\hline $\begin{array}{l}\text { 1. Marked fibrosis/architectural distortion, } \pm \\
\text { honeycombing in a predominantly } \\
\text { subpleural/paraseptal distribution }\end{array}$ & $\begin{array}{l}\text { 1. Marked fibrosis/architectural } \\
\text { distortion, } \pm \text { honeycombing }\end{array}$ & $\begin{array}{l}\text { 1. Patch or diffuse involvement of } \\
\text { lung parenchyma by fibrosis, with or } \\
\text { without interstitial inflammation }\end{array}$ & $\begin{array}{l}\text { 1. Hyaline membranes } \\
\text { 2. Organizing pneumonia } \\
\text { 3. Granulomas }\end{array}$ \\
\hline $\begin{array}{l}\text { 2. Presence of patchy involvement of } \\
\text { lung parenchyma by fibrosis }\end{array}$ & $\begin{array}{l}\text { 2. Absence of either patchy } \\
\text { involvement or fibroblast } \\
\text { foci, but not both }\end{array}$ & $\begin{array}{l}\text { 2. Absence of other criteria for } \\
\text { UIP (see UIP pattern column) }\end{array}$ & $\begin{array}{l}\text { 4. Marked interstitial } \\
\text { inflammatory cell infiltrate } \\
\text { distant from honeycombing }\end{array}$ \\
\hline 3. Presence of fibroblast foci & $\begin{array}{l}\text { 3. Absence of features } \\
\text { against a diagnosis of } \\
\text { UIP suggesting an alternate } \\
\text { diagnosis (see fourth column) }\end{array}$ & $\begin{array}{l}\text { 3. Absence of features against a } \\
\text { diagnosis of UIP suggesting } \\
\text { an alternate diagnosis } \\
\text { (see fourth column) }\end{array}$ & $\begin{array}{l}\text { 5. Predominant airway } \\
\text { centered changes }\end{array}$ \\
\hline $\begin{array}{l}\text { 4. Absence of features against a } \\
\text { diagnosis of UIP suggesting an } \\
\text { alternate diagnosis } \\
\text { (see fourth column) }\end{array}$ & $\begin{array}{l}\text { OR } \\
\text { 4. Honeycomb changes only }\end{array}$ & & $\begin{array}{l}\text { 6. Other features suggestive of } \\
\text { an alternate diagnosis }\end{array}$ \\
\hline
\end{tabular}



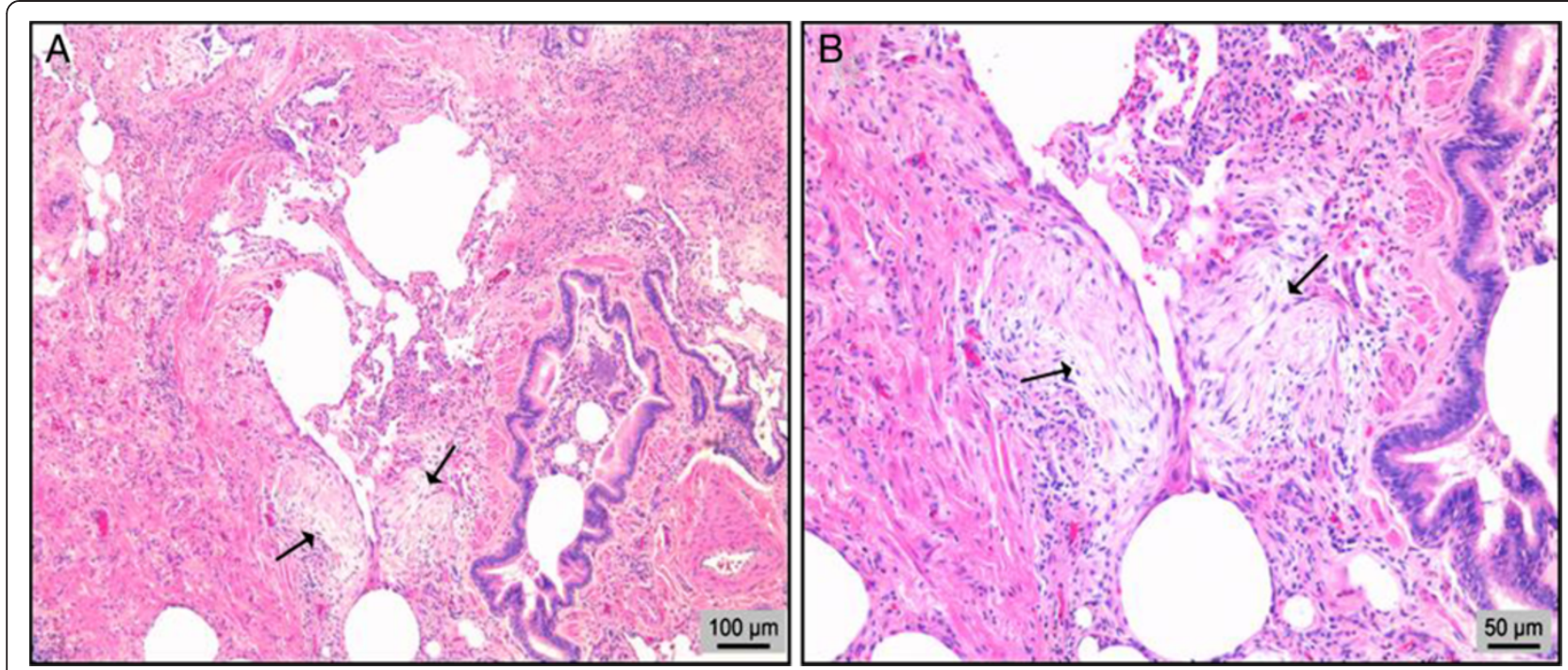

Figure 1 Histopathological findings of a surgical lung biopsy sample. A. An image showing histological features of usual interstitial pneumonia (UIP) including dense fibrosis, fibroblast foci (arrows) and only a few nearly normal looking alveolar walls (on the middle). B. Fibroblast foci (arrows) are seen at higher magnification. Haematoxylin-eosin (HE) stain.

by SLB $[19,22]$. In the major clinical trials conducted in the past decade, the current diagnostic criteria for IPF have been used which may provide some enlightenment on the frequency of SLB. In the Japanese studies examining pirfenidone, about $20-30 \%$ the IPF patients were biopsied. In contrast in the Capacity studies, the numbers of SLBs were much higher, with about $40-60 \%$ of biopsied patients (Table 2) [23-25]. The percentages of the SLBs were similar in the IFIGENIA and also in the first large interferon-study [26,27]. Furthermore, a high percentage of biopsies was encountered in the studies of INSPIRE, BUILD-1, imatinib and etanercept [28-31]. In the study of triple-kinase, the percentages of SLB were lower, by approximately $30 \%$ (Table 2) [32].

\section{Comparison of video-assisted thoracoscopic operation and open lung thoracotomy for SLB}

Several studies have shown that SLB taken by either open lung thoracotomy (OLB) or video-assisted thoracoscopic surgical (VATS) operation is an efficient diagnostic procedure for ILD [33-36]. Mouroux et al. compared the efficacy and safety of VATS and OLB in the diagnosis of ILD and revealed that in conjunction with compatible efficacy and similar morbidity and mortality, VATS offered several advantages such as reduction of the operative time and hospital stay [37]. In contrast, in a randomized and controlled trial, it was observed that there were no differences in outcomes for thoracoscopic and thoracotomic procedures [38]. The recent statement of IPF stated that the decision on which procedure to perform in the SLB needs to be based on individual patient characteristics and surgical expertise, and whether or not to pursue SLB should be evaluated depending on the clinical situation of the individual patient [1].

\section{Risks of SLB procedure}

The most common complication of SLB is prolonged air-leak which occurs in about $6-12 \%$ of the cases; other common complications can be a need for mechanical ventilation, pneumonia, pneumothorax, hemothorax, pleural effusion, empyema and prolonged ventilation [39-41]. In an Icelandic study, the general complication rate was $16 \%$ and the 30-day mortality was less than 3 percent [40]. The most serious complication is mortality within 30 days after the procedure which is commonly caused by an acute exacerbation of IPF, a phenomenon that is characterized by diffuse alveolar damage (DAD) superimposed on UIP [42]. The detailed mechanisms leading to DAD after the SLB procedure are not well known. After the first days of injury DAD is characterized by hyaline membranes, edema and interstitial acute inflammation, whereas later during the organizing phase alveolar septal thickening with loose organizing fibrosis, type II pneumocyte hyperplasia, and patchy or diffuse airspace organization exist. The histological feature of DAD is known to be associated also with many other lung diseases like acute interstitial pneumonia (AIP), severe viral lung infections and acute respiratory distress syndrome (ARDS) [42].

Table 3 lists the studies which have evaluated the mortality within 30 days after the SLB procedure [39-41,43-45]. In some studies, the mortality within 90 days was also evaluated. All studies were retrospective and the number of the patients has been rather low. In addition to IPF, some other types of ILDs like NSIP and 
Table 2 Number of biopsied IPF-patients in the clinical trials conducted during the past decade

\begin{tabular}{|c|c|c|}
\hline Study & $\begin{array}{l}\text { Number of } \\
\text { patients }\end{array}$ & $\begin{array}{l}\text { Number }(n) / \% \text { of } \\
\text { biopsied patients }\end{array}$ \\
\hline Pirfenidone & 107 & - pirfenidone: $n=15 / 21 \%$ \\
\hline $\begin{array}{l}\text { Azuma et al., } \\
\text { AJRCCM } 2005\end{array}$ & & - placebo: $n=8 / 23 \%$ \\
\hline Pirfenidone & 267 & - high dose: $n=26 / 24 \%$ \\
\hline \multirow{2}{*}{$\begin{array}{l}\text { Taniguchi et al., } \\
\text { Eur Respir J } 2010\end{array}$} & & - low dose: $n=16 / 29 \%$ \\
\hline & & - placebo: $n=28 / 27 \%$ \\
\hline Pirfenidone & CAPACITY I & CAPACITY I \\
\hline Noble et al., Lancet 2011 & 435 & - 1197 mg: $n=32 / 37 \%$ \\
\hline CAPACITY I & CAPACITY $\|$ & - 2403 mg: $n=86 / 49 \%$ \\
\hline \multirow[t]{3}{*}{ CAPACITY $\|$} & 334 & $\begin{array}{l}\text { - placebo: } n=85 / 49 \% \\
\text { CAPACITY } \|\end{array}$ \\
\hline & & - pirfenidone: $n=94 / 55 \%$ \\
\hline & & - placebo: $n=94 / 54 \%$ \\
\hline Triple-therapy & 155 & - triple therapy: $n=38 / 48 \%$ \\
\hline $\begin{array}{l}\text { Demedts et al., } \\
\text { NEJM } 2005\end{array}$ & & - control: $n=35 / 47 \%$ \\
\hline IFIGENIA & & - excluded patients: $n=24 / 89 \%$ \\
\hline Interferon gamma-1b & 330 & - IFN- $\gamma-1 \mathrm{~b}: 62 \%$ \\
\hline Raghu et al., NEJM 2004 & & - placebo: 67\% \\
\hline Interferon gamma-1b & 826 & - IFN- -1 -1b: $n=305 / 55 \%$ \\
\hline King et al., & & - placebo $n=151 / 55 \%$ \\
\hline \multicolumn{3}{|l|}{ Lancet 2009} \\
\hline \multicolumn{3}{|l|}{ INSPIRE } \\
\hline Bosentan & 158 & - bosentan: 68\% \\
\hline King et al., & & - placebo: 60\% \\
\hline \multicolumn{3}{|l|}{ AJRCCM 2008} \\
\hline \multicolumn{3}{|l|}{ BUILD-1 } \\
\hline Imatinib & 119 & - imatinib: $n=25 / 42 \%$ \\
\hline Daniels et al., & & - placebo: $n=29 / 48 \%$ \\
\hline \multicolumn{3}{|l|}{ AJRCCM 2010} \\
\hline Etanercept & 88 & - etanercept: $n=28 / 46 \%$ \\
\hline Raghu et al., & & - placebo: $n=23 / 41 \%$ \\
\hline \multicolumn{3}{|l|}{ AJRCCM 2008} \\
\hline Triple-kinase & 432 & - placebo: $n=19 / 22 \%$ \\
\hline Richeldi et al., & & $-50 m g \times 1: n=25 / 29 \%$ \\
\hline \multirow[t]{3}{*}{ NEJM 2011} & & $-50 m g \times 2: n=27 / 31 \%$ \\
\hline & & $-100 m g \times 2: n=20 / 23 \%$ \\
\hline & & $-150 m g \times 2: n=29 / 34 \%$ \\
\hline
\end{tabular}

connective tissue disease associated interstitial lung diseases (CTD-ILD) have been also included in most of the studies. The study of Utz and co-authors revealed the highest mortality, nearly $17 \%$ [45]. In that particular study, in which the patients were operated during the years 1986-1995, most of the biopsies had been taken by open thoracotomy and less by video-assisted thoracoscopic operation, while in other studies only a minority of the patients had been operated by open thoracotomic surgery. In most of the studies, the mortality was lower than in that reported by Utz, namely approximately $3-4 \%$ $[39,40,43,44]$. In the study by Park and co-authors no difference in mortality between OLB and VATS was observed, while in another study no mortality in the patients operated by VATS was observed since all the patients who had died within 30 days had been operated by OLB [44]. The number of the SLBs in these studies has been variable. In the study of Tiitto et al. only one SLB was taken from most of the patients [44], whereas in some other studies, the number of the biopsies varied from 2 to 4 with no marked effect on the complication rate or the short term mortality $[39,41]$. In the abovementioned studies, the risk factors for the mortality within 30 days were the existence of acute exacerbation of IPF at time of biopsy, low diffusion capacity (DLCO), mechanical ventilation, immunologic treatment, OLB and an age of more than 67 years.

The study of Park et al. showed that SLB performed at the time of acute exacerbation of IPF resulted in higher 30 -day mortality (28.6\%) compared to the patients without acute exacerbation (3.0\%) [39]. Utz and co-authors presented in their study that 10 of 68 patients with UIP died within 30 days after the procedure, when accelerated decline of the disease was the reason for performing SLB in $4(40 \%)$ patients [45]. Fibla and others observed that 28 (9\%) of 331 patients died within 30 days, of which 9 was in preoperative intensive care treatment [41]. That particular study revealed high rate for severe complications like acute exacerbation for respiratory failure (26.1\%) and postoperative need for intensive care (22.7\%).

Because of the retrospective and descriptive nature of the studies, it is difficult to draw any firm conclusions on the risk factors or limits for SLB. On the other hand, it is probable that no controlled clinical trial will be performed on this particular topic in the future. If one wishes a more accurate estimation of the risks of SLB, then larger patient material from multicenter studies may be required. A new method for performing SLB has been recently presented, such as awake thoracoscopic biopsy, which was shown to be feasible requiring only regional anesthesia and it has resulted in low morbidity, excellent diagnostic yields, short hospital stays, and low costs [46].

\section{Accuracy of histologic diagnosis and histologic variability of SLB}

It has been shown that there exists an inter-observer variability between pathologists when analyzing SLB samples. The study of Nicholson et al. revealed that there was only fair agreement among pathologists who 
Table 3 Studies of mortality within $\mathbf{3 0}$ days after the surgical lung biopsy procedure

\begin{tabular}{|c|c|c|c|c|c|}
\hline Study & Patients & Type of biopsy & Number of biopsies/Period & $\begin{array}{l}\text { Mortality } 30 \text { days } \\
\text { (90 days) }\end{array}$ & Risk factors \\
\hline \multirow[t]{3}{*}{$\begin{array}{l}\text { Utz et al., } \\
\text { Eur Respir J } 2001\end{array}$} & $\mathrm{IPF}=46$ & OLB 73\% & No of biopsies not described & $\begin{array}{l}-16.7 \% \text { in total } \\
\text { population }\end{array}$ & $\begin{array}{l}\text { - 4/10 had AE-IPF } \\
\text { before SLB }\end{array}$ \\
\hline & \multirow[t]{2}{*}{ CTD-UIP $=14$} & \multirow[t]{2}{*}{ VATS $27 \%$} & \multirow[t]{2}{*}{ 1986-1995 } & - All IPF & \multirow[t]{2}{*}{ - Lower DLCO } \\
\hline & & & & $-21.7 \%$ in IPF & \\
\hline \multirow{3}{*}{$\begin{array}{l}\text { Lettieri et al., } \\
\text { Chest } 2005\end{array}$} & $\mathrm{IPF}=42$ & OLB (no?) & No of biopsies not described & $-4.8 \%$ & - Mechanical ventilation \\
\hline & \multirow[t]{2}{*}{ Non-IPF $=41$} & \multirow[t]{2}{*}{ VATS (no?) } & \multirow[t]{2}{*}{ 1996-2002 } & $(5 / 6 \%)$ & \multirow[t]{2}{*}{ - Immunologic treatmen } \\
\hline & & & & $\begin{array}{l}\text { - No difference IPF } \\
\text { vs non-IPF, VATS vs OLB }\end{array}$ & \\
\hline \multirow{2}{*}{$\begin{array}{l}\text { Tiitto et al., } \\
\text { Chest } 2005\end{array}$} & $\mathrm{IPF}=64$ & OLB $n=42$ & 1 & - OLB 5.3\% & \multirow[t]{2}{*}{ - OLB } \\
\hline & CTD-UIP $=12$ & VATS $n=34$ & 1973-2002 & - VATS 0\% & \\
\hline \multirow{4}{*}{$\begin{array}{l}\text { Park et al., Eur J } \\
\text { Cardio-Thorac Surg } 2007\end{array}$} & $\mathrm{IPF}=140$ & OLB $n=50$ & $2-3$ & $-4 \%$ & - AE-IPF \\
\hline & $\mathrm{NSIP}=46$ & \multirow[t]{3}{*}{ VATS $n=150$} & \multirow[t]{3}{*}{ 1990-2003 } & \multirow[t]{3}{*}{$(8 \%)$} & \multirow[t]{3}{*}{- DLCO $<50 \%$} \\
\hline & $\mathrm{COP}=14$ & & & & \\
\hline & No ICU patients & & & & \\
\hline \multirow{4}{*}{$\begin{array}{l}\text { Sigurdsson et al., } \\
\text { Ann Thorac Surg } 2009\end{array}$} & $\mathrm{UIP}=23$ & OLB $n=45$ & 1: $70 \%$ & $-3 \%$ & \multirow{4}{*}{$\begin{array}{l}\text { - No data of } \\
\text { different ILDs }\end{array}$} \\
\hline & $\mathrm{OP}=17$ & VATS $n=28$ & $2: 20 \%$ & $(4 \%)$ & \\
\hline & $\mathrm{NSIP}=6$ & & \multirow[t]{2}{*}{ 1986-2007 } & \multirow{2}{*}{$\begin{array}{l}\text { - No difference OLB } \\
\text { vs VATS }\end{array}$} & \\
\hline & Others $=27$ & & & & \\
\hline \multirow{6}{*}{$\begin{array}{l}\text { Fibla et al., Int J } \\
\text { Cardiovasc Thorac Surg } 2012\end{array}$} & $\mathrm{IPF}=122$ & OLB 10\% & 1: $16 \%$ & VATS 9\% & - Age $>67$ \\
\hline & $\mathrm{COP}=31$ & VATS $90 \%$ & $2: 64 \%$ & OLB $10.6 \%$ & - OLB \\
\hline & RBILD = 16 & & 3: $59 \%$ & & - Immunologic treatment \\
\hline & $N S I P=13$ & & 4: $1 \%$ & & \multirow{3}{*}{$\begin{array}{l}\text { - No data of } \\
\text { different ILDs }\end{array}$} \\
\hline & Others $=114$ & & \multirow[t]{2}{*}{$2002-2009$} & & \\
\hline & $6 \%$ in ICU & & & & \\
\hline
\end{tabular}

Abbreviations:

$A E-I P F$ acute exacerbation of idiopathic pulmonary fibrosis.

$C O P$ cryptogenic organizing pneumonia.

CTD-ILD connective tissue associated interstitial lung disease.

DLCO diffusion capacity.

ILD interstitial lung disease.

ICU intensive care unit.

IPF idiopathic pulmonary fibrosis.

NSIP nonspecific interstitial pneumonia.

$O L B$ open lung thoracotomy.

$R B I L D$ respiratory bronchiolitis and interstitial lung disease.

$S L B$ surgical lung biopsy.

VATS video-assisted thoracoscopic operation.

had been provided with very little clinical information of the patients [47]. The previous studies analyzing the inter-observer error among clinicians and radiologists have shown similar kinds of results $[48,49]$. The multicenter study of Thomeer et al. observed a fair agreement in histological analysis between several investigators, with those of HRCT analyses were fair to moderate [50]. In that particular study, the lung biopsy material comprised of 44 SLB and 38 transbronchial biopsy samples, which might have had some effect on the result. The accuracy of diagnosis has been shown to be higher among expert specialists than the corresponding value made by physicians in the referring centers [5].
Some studies have indicated that the histological features may be variable in some cases of IPF since in some lobes or segments of lung NSIP-like features can exist in addition of UIP features. The patients with the coexistence of both NSIP and UIP patterns seemed to behave similarly to those with only a UIP pattern [51,52]. Sampling errors may result if only one biopsy is taken since it has been shown that in $26 \%$ of the cases, the histological classification would have been different between UIP and NSIP if only one biopsy had been taken. These findings laid the foundation for the current recommendation that SLB should be taken from a minimum of two lobes, and preferably more [51]. 
NSIP is nowadays a recognized entity exhibiting, however, overlapping features with other types of IIPs and hypersensitivity pneumonia. Unlike IPF, the prognosis of NSIP is good and it occurs mostly in middle-aged women who are never-smokers [53]. At present, the evidence that fibrotic form of NSIP is a precursor of UIP is weak. Possibly a subset of patients mistakenly diagnosed as having fibrotic NSIP may ultimately prove to have IPF. Familial form of IIP has been often called as familial IPF. A recent study showed, however, that less than half of the patients with familial IIP had histological strictly defined UIP features, but rather more often unclassifiable fibrosis [54].

\section{SLB as a tool for a marker of prognosis and the significance of fibroblast foci}

In addition of the diagnosis of ILD, SLB can be used also as source of a biomarker for the prognosis in IPF patients. The number of fibroblast foci (FF) i.e. active centers of fibrogenesis consisting of myofibroblasts, fibroblasts and extracellular matrix (ECM) proteins and lined by regenerative hyperplastic or metaplastic alveolar epithelium, has been shown to correlate with patient survival in several studies [47,55-59], but not in all [60] (Table 4). The detailed information of the studies focusing on the number of fibroblast foci is presented in the Table 4.

Despite this quite convincing evidence, the counting of FF in biopsies has not yet become a common routine clinical practice. This might be attributable to the fact that the number of FF has been evaluated with variable methods in the different studies. At present FF has proved to be the only reproducible histological factor that correlates with the prognosis in IPF. There are very few studies, which have evaluated the value of immunohistochemical markers from SLB specimens on survival, since during the past decade most studies focusing on biomarkers have been conducted by using serum or BAL samples. Nearly two decades ago it was reported that a high expression level of the ECM protein, tenascin- $\mathrm{C}$ as detected by immunohistochemistry in SLB samples, correlated with shortened survival in patients with UIP [61].

\section{Transbronchial biopsy in the diagnosis of IPF}

Neither the previous nor the current statement has recommended TBB for the diagnosis of IPF; this technique has been used mainly to exclude other ILDs such as sarcoidosis, or malignancies and infections $[1,4]$. The study of Berbescu et al. however showed that characteristic histologic features of UIP could be identified from TBB specimens more often than previously appreciated observing changes diagnostic of UIP in $43 \%$ of the cases [62]. Another study showed that TBB could reveal a UIP pattern in about $30 \%$ of the cases [63]. In contrast Shim and others found UIP features in only $9.4 \%$ of the patients [64]. In a recent review article it was presented that in the right clinical setting and with appropriate tissue sampling TBB can support a diagnosis of UIP fairly often being especially useful in elderly patients or those with advanced fibrosis in whom there is significant mortality and morbidity from SBL [65]. It is notable that TBB samples in the abovementioned studies have been analyzed by the expert pulmonary pathologists, which may emphasize the need for refer these cases to the specialized centers. A previous study showed that by using a novel technique for $\mathrm{TBB}$, namely transbronchial cryobiopsy, the size of TBB samples were much larger than those obtained using forceps [66]. In a recent prospective study TBB cryobiopsy samples obtained from 40 patients were evaluated, of which in $85 \%$ of the cases at least two of three typical UIP features were present [67].

\section{Conclusion}

It is probable that approximately one third of the IPF patients would need SLB in order to obtain an accurate diagnosis. Several remarkable points should be considered when making a decision whether or not to perform the SLB. The mortality, which can occur shortly after the procedure, has probably been the major reason to refrain from performing SLB. The precise risk limits for complications of SLB procedure are not well known. Thus a thorough deliberation taking into consideration age, other diseases, medication, lung function and the stage of the pulmonary fibrosis are needed before proceeding to a procedure of SLB. As it has been noted in the new statement, in patients with severe physiologic impairment or substantial comorbidity, the risks of SLB may outweigh the benefits of establishing a secure diagnosis of IPF, and moreover, clinicians must spend adequate time with patients to discuss patients' values and preferences [1].

The accuracy of the histological diagnosis might be problematic, and thus it seems to be fundamental that SLB are analyzed by experienced pulmonary pathologists. It is probable that the histological diagnosis may become even more challenging than previously when only the patients with non-typical HRCT features are biopsied, and UIP may be at risk of remaining obscured by other concomitant diseases or confounding factors. Moreover, the challenge of pulmonary pathology will be greater because of the fact that more complex and less classical lung diseases will be investigated that will make classification of histological patterns more difficult and may limit the role of pathology as a routine predictor of prognosis. Evaluation of the pathological archives from previous decades might help in the training of pulmonary pathologists and for gathering experience from a large amount of samples including also the typical cases representing IPF/UIP. It is likely 
Table 4 Studies of the association between the numbers of fibroblast foci (FF) to the prognosis of IPF

\begin{tabular}{|c|c|c|}
\hline Study & Patients and method & Results \\
\hline \multirow[t]{3}{*}{ King et al., Am J Respir Crit Care Med 2001} & $87 \mathrm{IPF}$ & \multirow{3}{*}{$\begin{array}{l}\text { Granulation/connective tissue score i.e. FF } \\
\text { was a significant predictor of survival } \\
\text { in patients with IPF }\end{array}$} \\
\hline & Semiquantitative & \\
\hline & $\begin{array}{l}\text { Stainings: HE, pentachrome, Prussian } \\
\text { blue and toluidine blue }\end{array}$ & \\
\hline \multirow[t]{3}{*}{ Nicholson et al., Am J Respir Crit Care Med 2002} & $53 \mathrm{IPF}$ & \multirow{3}{*}{$\begin{array}{l}\text { Mortality of the patients was linked to an } \\
\text { increasing FF score, which associated also } \\
\text { with greater declines in FVC and DLCO }\end{array}$} \\
\hline & Semiquantitative & \\
\hline & Staining not described & \\
\hline \multirow[t]{3}{*}{ Flaherty et al., Am J Respir Crit Care Med 2003} & $\begin{array}{l}99 \text { IPF and } 9 \text { with connective tissue } \\
\text { disease (CTD-UIP) }\end{array}$ & $\begin{array}{l}\text { The profusion of FF associated with the } \\
\text { survival of UIP in whole study material, } \\
\text { but not in IPF }\end{array}$ \\
\hline & Semiquantitative & \multirow[t]{2}{*}{$\begin{array}{l}\text { The patients with IPF had higher profusion } \\
\text { of FF than the patients with CTD-UIP }\end{array}$} \\
\hline & Staining not described & \\
\hline \multirow[t]{3}{*}{ Tiitto et al., Thorax 2006} & 64 IPF and 12 CTD-UIP & \multirow{2}{*}{$\begin{array}{l}\text { The number of FF correlated with the } \\
\text { survival of the patients. The patients } \\
\text { with } \leq 50 \mathrm{FF} / \mathrm{cm}^{2} \text { had a median survival } \\
\text { of } 89 \text { months compared with } 49 \text { months } \\
\text { in those with }>50 \mathrm{FF} / \mathrm{cm}^{2}\end{array}$} \\
\hline & $\begin{array}{l}\text { The total number of FF was counted in } \\
\text { the area of which was defined by image analysis. } \\
\text { The number of FF was divided into two subgroups } \\
(\leq 50 \text { or }>50 \mathrm{FF} / \mathrm{cm} 2)\end{array}$ & \\
\hline & Stainings: AB-PAS and HE & $\begin{array}{l}\text { The number of FF was lower in } \\
\text { CTD-UIP than in IPF }\end{array}$ \\
\hline \multirow[t]{3}{*}{ Enomoto et al., Chest 2006} & $53 \mathrm{IPF}$ & \multirow{3}{*}{$\begin{array}{l}\text { \%FF score was a significant predictor } \\
\text { of survival in IPF patients }\end{array}$} \\
\hline & $\begin{array}{l}\text { Images of sections were studied by image analysis. \% } \\
\text { FF was calculated by dividing the area of FF by that } \\
\text { of the target field. Overall \%FF in each patient was } \\
\text { defined as the average } \% \mathrm{FF}>10 \text { selected cases }\end{array}$ & \\
\hline & HE staining & \\
\hline \multirow[t]{3}{*}{ Hanak et al., Respir Med 2008} & $43 \mathrm{IPF}$ & \multirow{3}{*}{$\begin{array}{l}\text { No significant relationship between } \\
\text { FF profusion and survival }\end{array}$} \\
\hline & $\begin{array}{l}\text { FF was counted by using a conventional point- } \\
\text { counting technique. The number of points } \\
\text { intersecting FF was expressed as a fraction of the } \\
\text { total points counted on each slide and a mean value } \\
\text { was calculated }\end{array}$ & \\
\hline & Staining not described & \\
\hline \multirow[t]{3}{*}{ Lee et al., Sarcoidosis Vasc Diffuse Lung Dis 2011} & $86 \mathrm{IPF}$ & \multirow[t]{3}{*}{ FF score associated with survival } \\
\hline & Semiquantitive & \\
\hline & Staining not described & \\
\hline
\end{tabular}

Abbreviations:

$A E-I P F$ acute exacerbation of idiopathic pulmonary fibrosis.

$A B$-PAS Alcian blues periodic acid Schiff.

$C O P$ cryptogenic organizing pneumonia.

CTD-ILD connective tissue associated interstitial lung disease.

DLCO diffusion capacity.

HE haematoxylin-eosin.

ILD interstitial lung disease.

ICU intensive care unit.

IPF idiopathic pulmonary fibrosis.

NSIP nonspecific interstitial pneumonia.

$R B I L D$ respiratory bronchiolitis and interstitial lung disease.

OLB surgical lung biopsy taken by thoracotomic surgical operation.

VATS surgical lung biopsy taken bb video-assisted thoracotomic surgical operation.

that more SLB may be needed for the diagnosis of NSIP and for the exclusion of IPF, especially after the preliminary results of the Panther-study which revealed a harmful effect of triple therapy treated IPF patients [68].
Since many IPF patients are at an older age and suffer from many other diseases, or their lung disease has already progressed to an advanced stage, SLB cannot be considered as a safe procedure for all individuals. Thus, there is a definite need for developing new diagnostic 
tools for the diagnosis of IPF and other ILDs. According to the current statement, $\mathrm{BAL}$ or $\mathrm{TBB}$ are no longer required for the diagnosis of IPF. A new BAL guideline has been recently published [69] as has as a new BAL cell culture technique for diagnostic samples [70]. Hopefully, BAL and TBB will gain greater acceptance in IPF diagnostics in the future with the development of more standardized techniques and innovative methodologies. Improvements in all methodological techniques including radiology and also the invasive procedures such as SLB, TBB and BAL could be predicted to make the diagnostics of IPF and other type of ILDs not only faster and safer but also more accurate, which will be important in the future due to a new classification of IIP including a category of unclassifiable ILD $[71,72]$.

\section{Competing interest}

The author declares that she has no competing interests.

\section{Acknowledgement}

The study was supported by the Jalmari and Rauha Ahokas Foundation, the Finnish Anti-Tuberculosis Association Foundation, a state subsidy to the University Hospitals of Oulu and Kuopio, and the Health Care Foundation of North Finland. The author would like to kindly acknowledge Dr. Elisa LappiBlanco for her expert comments.

\section{Author details}

${ }^{1}$ Unit of Medicine and Clinical Research, Pulmonary Division, University of Eastern Finland, PO Box 1777, Kuopio 70211, Finland. ${ }^{2}$ Center for Medicine and Clinical Research, Division of Respiratory Medicine, Kuopio University Hospital, PO Box 1777, Kuopio 70211, Finland. ${ }^{3}$ Respiratory Research Unit and Clinical Research Center, Oulu University Hospital, Oulu, Finland.

Received: 1 March 2013 Accepted: 10 April 2013

Published: 15 April 2013

\section{References}

1. Raghu G, Collard HR, Egan JJ, Martinez FJ, Behr J, Brown KK, Colby TV, Cordier JF, Flaherty KR, Lasky JA, Lynch DA, Ryu JH, Swigris JJ, Wells AU, Ancochea J, Bouros D, Carvalho C, Costabel U, Ebina M, Hansell DM, Johkoh T, Kim DS, King TE Jr, Kondoh Y, Myers J, Muller NL, Nicholson AG, Richeldi L, Selman M, Dudden RF, Griss BS, Protzko SL, Schunemann HJ: An official ATS/ERS/JRS/ALAT statement: idiopathic pulmonary fibrosis: evidencebased guidelines for diagnosis and management. Am J Respir Crit Care Med 2011, 183:788-824.

2. Fishbein MC: Diagnosis: to biopsy or not to biopsy: assessing the role of surgical lung biopsy in the diagnosis of idiopathic pulmonary fibrosis. Chest 2005, 128:520S-525S

3. Glaspole IN, Wells AU, du Bois RM: Lung biopsy in diffuse parenchymal lung disease. Monaldi Arch Chest Dis 2001, 56:225-232.

4. American Thoracic Society: Idiopathic pulmonary fibrosis: diagnosis and treatment. International consensus statement. American Thoracic Society (ATS), and the European Respiratory Society (ERS). Am J Respir Crit Care Med 2000, 161:646-664.

5. Flaherty KR, King TE Jr, Raghu G, Lynch JP III, Colby TV, Travis WD, Gross BH, Kazerooni EA, Toews GB, Long Q, Murray S, Lama VN, Gay SE, Martinez FJ: Idiopathic interstitial pneumonia: what is the effect of a multidisciplinary approach to diagnosis? Am J Respir Crit Care Med 2004, 170:904-910.

6. Raghu G, Mageto YN, Lockhart D, Schmidt RA, Wood DE, Godwin JD: The accuracy of the clinical diagnosis of new-onset idiopathic pulmonary fibrosis and other interstitial lung disease: a prospective study. Chest 1999, 116:1168-1174.

7. Flaherty KR, Thwaite EL, Kazerooni EA, Gross BH, Toews GB, Colby TV, Travis WD, Mumford JA, Murray S, Flint A, Lynch JP III, Martinez FJ: Radiological versus histological diagnosis in UIP and NSIP: survival implications. Thorax 2003, 58:143-148.
8. Hunninghake GW, Zimmerman MB, Schwartz DA, King TE Jr, Lynch J, Hegele R, Waldron J, Colby T, Muller N, Lynch D, Galvin J, Gross B, Hogg J, Toews G, Helmers R, Cooper JA Jr, Baughman R, Strange C, Millard M: Utility of a lung biopsy for the diagnosis of idiopathic pulmonary fibrosis. Am J Respir Crit Care Med 2001, 164:193-196.

9. Lynch DA, Travis WD, Muller NL, Galvin JR, Hansell DM, Grenier PA, King TE Jr: Idiopathic interstitial pneumonias: CT features. Radiology 2005, 236:10-21.

10. Lynch DA, Godwin JD, Safrin S, Starko KM, Hormel P, Brown KK, Raghu G, King TE Jr, Bradford WZ, Schwartz DA, Richard WW: High-resolution computed tomography in idiopathic pulmonary fibrosis: diagnosis and prognosis. Am J Respir Crit Care Med 2005, 172:488-493.

11. Mink SN, Maycher B: Comparative manifestations and diagnostic accuracy of high-resolution computed tomography in usual interstitial pneumonia and nonspecific interstitial pneumonia. Curr Opin Pulm Med 2012, 18:530-534.

12. Silva Cl, Muller NL, Hansell DM, Lee KS, Nicholson AG, Wells AU: Nonspecific interstitial pneumonia and idiopathic pulmonary fibrosis: changes in pattern and distribution of disease over time. Radiology 2008, 247:251-259.

13. Sverzellati N, Wells AU, Tomassetti S, Desai SR, Copley SJ, Aziz ZA, Zompatori M, Chilosi M, Nicholson AG, Poletti V, Hansell DM: Biopsy-proved idiopathic pulmonary fibrosis: spectrum of nondiagnostic thin-section CT diagnoses. Radiology 2010, 254:957-964.

14. Elliot TL, Lynch DA, Newell JD Jr, Cool C, Tuder R, Markopoulou K, Veve R, Brown KK: High-resolution computed tomography features of nonspecific interstitial pneumonia and usual interstitial pneumonia. J Comput Assist Tomogr 2005, 29:339-345.

15. MacDonald SL, Rubens MB, Hansell DM, Copley SJ, Desai SR, du Bois RM, Nicholson AG, Colby TV, Wells AU: Nonspecific interstitial pneumonia and usual interstitial pneumonia: comparative appearances at and diagnostic accuracy of thin-section CT. Radiology 2001, 221:600-605.

16. Silva Cl, Muller NL, Lynch DA, Curran-Everett D, Brown KK, Lee KS, Chung MP, Churg A: Chronic hypersensitivity pneumonitis: differentiation from idiopathic pulmonary fibrosis and nonspecific interstitial pneumonia by using thin-section CT. Radiology 2008, 246:288-297.

17. Fernandez Perez ER, Daniels CE, Schroeder DR, St Sauver J, Hartman TE, Bartholmai BJ, Yi ES, Ryu JH: Incidence, prevalence, and clinical course of idiopathic pulmonary fibrosis: a population-based study. Chest 2010, 137:129-137.

18. Hodgson U, Laitinen T, Tukiainen P: Nationwide prevalence of sporadic and familial idiopathic pulmonary fibrosis: evidence of founder effect among multiplex families in Finland. Thorax 2002, 57:338-342.

19. Karakatsani A, Papakosta D, Rapti A, Antoniou KM, Dimadi M, Markopoulou A, Latsi P, Polychronopoulos V, Birba G, Ch L, Bouros D: Epidemiology of interstitial lung diseases in Greece. Respir Med 2009, 103:1122-1129.

20. Thomeer $M$, Demedts $M$, Vandeurzen $K$ : Registration of interstitial lung diseases by 20 centres of respiratory medicine in Flanders. Acta Clin Belg 2001, 56:163-172.

21. Tinelli C, De Silvestri A, Richeldi L, Oggionni T: The Italian register for diffuse infiltrative lung disorders (RIPID): a four-year report. Sarcoidosis Vasc Diffuse Lung Dis 2005, 22(Suppl 1):S4-S8.

22. Xaubet $A$, Ancochea J, Morell F, Rodriguez-Arias JM, Villena V, Blanquer $R$, Montero C, Sueiro A, Disdier C, Vendrell M: Report on the incidence of interstitial lung diseases in Spain. Sarcoidosis Vasc Diffuse Lung Dis 2004, 21:64-70.

23. Azuma A, Nukiwa T, Tsuboi E, Suga M, Abe S, Nakata K, Taguchi Y, Nagai S, Itoh H, Ohi M, Sato A, Kudoh S: Double-blind, placebo-controlled trial of pirfenidone in patients with idiopathic pulmonary fibrosis. Am J Respir Crit Care Med 2005, 171:1040-1047.

24. Noble PW, Albera C, Bradford WZ, Costabel U, Glassberg MK, Kardatzke D, King TE Jr, Lancaster L, Sahn SA, Szwarcberg J, Valeyre D, du Bois RM: Pirfenidone in patients with idiopathic pulmonary fibrosis (CAPACITY): two randomised trials. Lancet 2011, 377:1760-1769.

25. Taniguchi H, Ebina M, Kondoh Y, Ogura T, Azuma A, Suga M, Taguchi Y, Takahashi H, Nakata K, Sato A, Takeuchi M, Raghu G, Kudoh S, Nukiwa T: Pirfenidone in idiopathic pulmonary fibrosis. Eur Respir J 2010, 35:821-829.

26. Demedts M, Behr J, Buhl R, Costabel U, Dekhuijzen R, Jansen HM, MacNee W, Thomeer M, Wallaert B, Laurent F, Nicholson AG, Verbeken EK, Verschakelen J, Flower CD, Capron F, Petruzzelli S, De Vuyst P, van den Bosch JM, Rodriguez-Becerra E, Corvasce G, Lankhorst I, Sardina M, Montanari M: High-dose acetylcysteine in idiopathic pulmonary fibrosis. N Engl J Med 2005, 353:2229-2242. 
27. Raghu G, Brown KK, Bradford WZ, Starko K, Noble PW, Schwartz DA, King TE $\mathrm{Jr}$ : A placebo-controlled trial of interferon gamma-1b in patients with idiopathic pulmonary fibrosis. N Engl J Med 2004, 350:125-133.

28. Daniels CE, Lasky JA, Limper AH, Mieras K, Gabor E, Schroeder DR: Imatinib treatment for idiopathic pulmonary fibrosis: Randomized placebocontrolled trial results. Am J Respir Crit Care Med 2010, 181:604-610.

29. King TE Jr, Behr J, Brown KK, du Bois RM, Lancaster L, de Andrade JA, Stahler G, Leconte I, Roux S, Raghu G: BUILD-1: a randomized placebocontrolled trial of bosentan in idiopathic pulmonary fibrosis. Am J Respir Crit Care Med 2008, 177:75-81.

30. King TE Jr, Albera C, Bradford WZ, Costabel U, Hormel P, Lancaster L, Noble PW, Sahn SA, Szwarcberg J, Thomeer M, Valeyre D, du Bois RM: Effect of interferon gamma-1b on survival in patients with idiopathic pulmonary fibrosis (INSPIRE): a multicentre, randomised, placebocontrolled trial. Lancet 2009, 374:222-228.

31. Raghu G, Brown KK, Costabel U, Cottin V, du Bois RM, Lasky JA, Thomeer M, Utz JP, Khandker RK, McDermott L, Fatenejad S: Treatment of idiopathic pulmonary fibrosis with etanercept: an exploratory, placebo-controlled trial. Am J Respir Crit Care Med 2008, 178:948-955.

32. Richeldi L, Costabel U, Selman M, Kim DS, Hansell DM, Nicholson AG, Brown KK, Flaherty KR, Noble PW, Raghu G, Brun M, Gupta A, Juhel N, Kluglich M, du Bois RM: Efficacy of a tyrosine kinase inhibitor in idiopathic pulmonary fibrosis. N Engl J Med 2011, 365:1079-1087.

33. Bensard DD, Mclntyre RC Jr, Waring BJ, Simon JS: Comparison of video thoracoscopic lung biopsy to open lung biopsy in the diagnosis of interstitial lung disease. Chest 1993, 103:765-770.

34. Ferson PF, Landreneau RJ, Dowling RD, Hazelrigg SR, Ritter P, Nunchuck S, Perrino MK, Bowers CM, Mack MJ, Magee MJ: Comparison of open versus thoracoscopic lung biopsy for diffuse infiltrative pulmonary disease. J Thorac Cardiovasc Surg 1993, 106:194-199.

35. Molin LJ, Steinberg JB, Lanza LA: VATS increases costs in patients undergoing lung biopsy for interstitial lung disease. Ann Thorac Surg 1994, 58:1595-1598.

36. Rena O, Casadio C, Leo F, Giobbe R, Cianci R, Baldi S, Rapellino M, Maggi G: Videothoracoscopic lung biopsy in the diagnosis of interstitial lung disease. Eur J Cardiothorac Surg 1999, 16:624-627.

37. Mouroux J, Clary-Meinesz C, Padovani B, Perrin C, Rotomondo C, Chavaillon JM, Blaive $B$, Richelme $\mathrm{H}$ : Efficacy and safety of videothoracoscopic lung biopsy in the diagnosis of interstitial lung disease. Eur J Cardiothorac Surg 1997, 11:22-26.

38. Miller JD, Urschel JD, Cox G, Olak J, Young JE, Kay JM, McDonald E: A randomized, controlled trial comparing thoracoscopy and limited thoracotomy for lung biopsy in interstitial lung disease. Ann Thorac Surg 2000, 70:1647-1650.

39. Park JH, Kim DK, Kim DS, Koh Y, Lee SD, Kim WS, Kim WD, Park SI: Mortality and risk factors for surgical lung biopsy in patients with idiopathic interstitial pneumonia. European Journal of Cardio-thoracic Surgery 2007; 31:1115-1119.

40. Sigurdsson MI, Isaksson HJ, Gudmundsson G, Gudbjartsson T: Diagnostic surgical lung biopsies for suspected interstitial lung diseases: a retrospective study. Ann Thorac Surg 2009, 88:227-232

41. Fibla JJ, Brunelli A, Cassivi SD, Deschamps C: Aggregate risk score for predicting mortality after surgical biopsy for interstitial lung disease. Interact Cardiovasc Thorac Surg 2012, 15:276-279.

42. Kaarteenaho R, Kinnula VL: Diffuse alveolar damage: a common phenomenon in progressive interstitial lung disorders. Pulm Med 2011, 2011:531302.

43. Lettieri CJ, Veerappan GR, Helman DL, Mulligan CR, Shorr AF: Outcomes and safety of surgical lung biopsy for interstitial lung disease. Chest 2005, 127:1600-1605.

44. Tiitto L, Heiskanen U, Bloigu R, Paakko P, Kinnula V, Kaarteenaho-Wiik R: Thoracoscopic lung biopsy is a safe procedure in diagnosing usual interstitial pneumonia. Chest 2005, 128:2375-2380.

45. Utz JP, Ryu JH, Douglas WW, Hartman TE, Tazelaar HD, Myers JL, Allen MS, Schroeder DR: High short-term mortality following lung biopsy for usual interstitial pneumonia. Eur Respir J 2001, 17:175-179.

46. Pompeo E, Rogliani P, Cristino B, Schillaci O, Novelli G, Saltini C: Awake thoracoscopic biopsy of interstitial lung disease. Ann Thorac Surg 2013, 95(2):445-52.

47. Nicholson AG, Fulford LG, Colby TV, du Bois RM, Hansell DM, Wells AU: The relationship between individual histologic features and disease progression in idiopathic pulmonary fibrosis. Am J Respir Crit Care Med 2002, 166:173-177

48. Aziz ZA, Wells AU, Hansell DM, Bain GA, Copley SJ, Desai SR, Ellis SM, Gleeson FV, Grubnic S, Nicholson AG, Padley SP, Pointon KS, Reynolds JH, Robertson RJ, Rubens MB: HRCT diagnosis of diffuse parenchymal lung disease: inter-observer variation. Thorax 2004, 59:506-511.

49. Peckham RM, Shorr AF, Helman DL Jr: Potential limitations of clinical criteria for the diagnosis of idiopathic pulmonary fibrosis/cryptogenic fibrosing alveolitis. Respiration 2004, 71:165-169.

50. Thomeer M, Demedts M, Behr J, Buhl R, Costabel U, Flower CD, Verschakelen J, Laurent F, Nicholson AG, Verbeken EK, Capron F, Sardina M, Corvasce G, Lankhorst I: Multidisciplinary interobserver agreement in the diagnosis of idiopathic pulmonary fibrosis. Eur Respir J 2008, 31:585-591.

51. Flaherty KR, Travis WD, Colby TV, Toews GB, Kazerooni EA, Gross BH, Jain A Strawderman RL, Flint A, Lynch JP, Martinez FJ: Histopathologic variability in usual and nonspecific interstitial pneumonias. Am J Respir Crit Care Med 2001, 164:1722-1727.

52. Monaghan H, Wells AU, Colby TV, du Bois RM, Hansell DM, Nicholson AG: Prognostic implications of histologic patterns in multiple surgical lung biopsies from patients with idiopathic interstitial pneumonias. Chest 2004, 125:522-526.

53. Travis WD, Hunninghake G, King TE Jr, Lynch DA, Colby TV, Galvin JR, Brown KK, Chung MP, Cordier JF, du Bois RM, Flaherty KR, Franks TJ, Hansell DM, Hartman TE, Kazerooni EA, Kim DS, Kitaichi M, Koyama T, Martinez FJ, Nagai S, Midthun DE, Muller NL, Nicholson AG, Raghu G, Selman M, Wells A: Idiopathic nonspecific interstitial pneumonia: report of an American Thoracic Society project. Am J Respir Crit Care Med 2008, 177:1338-1347.

54. Leslie KO, Cool CD, Sporn TA, Curran-Everett D, Steele MP, Brown KK, Wahidi MM, Schwartz DA: Familial idiopathic interstitial pneumonia: histopathology and survival in 30 patients. Arch Pathol Lab Med 2012, 136:1366-1376.

55. Enomoto $N$, Suda T, Kato M, Kaida Y, Nakamura Y, Imokawa S, Ida M Chida K: Quantitative analysis of fibroblastic foci in usual interstitial pneumonia. Chest 2006, 130:22-29.

56. King TE Jr, Schwarz MI, Brown K, Tooze JA, Colby TV, Waldron JA Jr, Flint A, Thurlbeck W, Cherniack RM: Idiopathic pulmonary fibrosis: relationship between histopathologic features and mortality. Am J Respir Crit Care Med 2001, 164:1025-1032.

57. Lee SH, Shim HS, Cho SH, Kim SY, Lee SK, Son JY, Jung JY, Kim EY, Lim JE, Lee KJ, Park BH, Kang YA, Kim YS, Kim SK, Chang J, Park MS: Prognostic factors for idiopathic pulmonary fibrosis: clinical, physiologic, pathologic, and molecular aspects. Sarcoidosis Vasc Diffuse Lung Dis 2011, 28:102-112.

58. Tiitto L, Bloigu R, Heiskanen U, Pääkkö P, Kinnula VL, Kaarteenaho-Wiik R: Relationship between histopathological features and the course of idiopathic pulmonary fibrosis/usual interstitial pneumonia. Thorax 2006, 61:1091-1095.

59. Flaherty KR, Colby TV, Travis WD, Toews GB, Mumford J, Murray S, Thannickal VJ, Kazerooni EA, Gross BH, Lynch JP 3rd, Martinez FJ: Fibroblast foci in usual interstitial pneumonia: idiopathic versus collagen vascular disease. Am J Respir Crit Care Med 2003; 167(10):1410-5.

60. Hanak V: Ryu JH, de CE, Limper AH, Hartman TE, Decker PA, Myers JL: Profusion of fibroblast foci in patients with idiopathic pulmonary fibrosis does not predict outcome. Respir Med 2008, 102:852-856.

61. Kaarteenaho-Wiik R, Tani T, Sormunen R, Soini Y, Virtanen I, Pääkkö P. Tenascin immunoreactivity as a prognostic marker in usual interstitial pneumonia. Am J Respir Crit Care Med 1996, 154:511-518.

62. Berbescu EA, Katzenstein AL, Snow JL, Zisman DA: Transbronchial biopsy in usual interstitial pneumonia. Chest 2006, 129:1126-1131.

63. Tomassetti S, Cavazza A, Colby TV, Ryu JH, Nanni O, Scarpi E, Tantalocco P, Buccioli M, Dubini A, Piciucchi S, Ravaglia C, Gurioli C, Casoni GL, Gurioli C, Romagnoli M, Poletti V: Transbronchial biopsy is useful in predicting UIP pattern. Respir Res 2012, 13:96.

64. Shim HS, Park MS, Park IK: Histopathologic findings of transbronchial biopsy in usual interstitial pneumonia. Pathol Int 2010, 60:373-377.

65. Katzenstein AL: Smoking-related interstitial fibrosis (SRIF), pathogenesis and treatment of usual interstitial pneumonia (UIP), and transbronchial biopsy in UIP. Mod Pathol 2012, 25(Suppl 1):S68-S78.

66. Babiak A, Hetzel J, Krishna G, Fritz P, Moeller P, Balli T, Hetzel M: Transbronchial cryobiopsy: a new tool for lung biopsies. Respiration 2009, 78:203-208. 
67. Casoni GL, Cavazza A, Dubini A, Tomassetti S, Romagnoli M, Ravaglia C, Gurioli C, Pietrangeli C, Poletti V: Identification of the pathological pattern by transbronchial lung cryobiopsies in patients with fibrosing diffuse parenchymal lung disease. Eur Respir J 2012, 40(Suppl 56):512. Abstract.

68. Raghu G, Anstrom KJ, King TE Jr, Lasky JA, Martinez FJ: Prednisone, azathioprine, and $\mathrm{N}$-acetylcysteine for pulmonary fibrosis. N Engl J Med 2012, 366:1968-1977.

69. Meyer KC, Raghu G, Baughman RP, Brown KK, Costabel U, du Bois RM, Drent M, Haslam PL, Kim DS, Nagai S, Rottoli P, Saltini C, Selman M, Strange C, Wood B: An official American Thoracic Society clinical practice guideline: the clinical utility of bronchoalveolar lavage cellular analysis in interstitial lung disease. Am J Respir Crit Care Med 2012, 185:1004-1014.

70. Karvonen HM, Lehtonen ST, Sormunen RT, Harju TH, Lappi-Blanco E, Bloigu RS, Kaarteenaho RL: Myofibroblasts in interstitial lung diseases show diverse electron microscopic and invasive features. Lab Invest 2012, 92:1270-1284.

71. Larsen BT, Colby TV: Update for pathologists on idiopathic interstitial pneumonias. Arch Pathol Lab Med 2012, 136:1234-1241.

72. Ryerson CJ, Urbania TH, Richeldi L, Mooney JJ, Lee JS, Jones KD, Elicker BM, Koth LL, King TE Jr, Wolters PJ, Collard HR: Prevalence and prognosis of unclassifiable interstitial lung disease. Eur Respir J 2012. Dec 6. (epub ahead of print).

doi:10.1186/1465-9921-14-43

Cite this article as: Kaarteenaho: The current position of surgical lung biopsy in the diagnosis of idiopathic pulmonary fibrosis. Respiratory Research 2013 14:43.

\section{Submit your next manuscript to BioMed Central and take full advantage of:}

- Convenient online submission

- Thorough peer review

- No space constraints or color figure charges

- Immediate publication on acceptance

- Inclusion in PubMed, CAS, Scopus and Google Scholar

- Research which is freely available for redistribution 